\title{
Mejora de la línea de llenado de una empresa del sector agroquímico mediante la aplicación de criterios de satisfacción CTS y el ciclo PHVA.
}

\section{Improvement of the filling line of a company of the agrochemical sector through the application of CTS satisfaction criteria and the PHVA cycle.}

DOI: http://doi.org/10.17981/bilo.2.1.2020.13

Artículo de Investigación Científica. Fecha de Recepción: 15/05/2020. Fecha de Aceptación: 14/06/2020

\author{
Isaac Alfaro \\ Universidad de la Costa CUC. Barranquilla, (Colombia) \\ ialfaro1@cuc.edu.co \\ Luz Jiménez-Mejia \\ Universidad de la Costa CUC. Barranquilla, (Colombia) \\ ljimenz57@cuc.edu.co \\ Miguel Ortiz-Barrios \\ Universidad de la Costa CUC. Barranquilla, (Colombia) \\ mortiz1@cuc.edu.co
}

Para citar este artículo:

I. Alfaro, L. Jiménez Mejia y M. Ortiz-Barrios, “Mejora de la línea de llenado de una empresa del sector agroquímico mediante la aplicación de criterios de satisfacción CTS y el ciclo PHVA", BILO, vol. 2, no. 1, 2020. DOI:

http://doi.org/10.17981/bilo.2.1.2020.13

\begin{abstract}
Resumen
Hoy las organizaciones tienen el desafío de adaptarse a un entorno que puede ser cambiante e impredecible, con un alto nivel de competencia y demanda para mejorar, crecer y desarrollarse de acuerdo con las necesidades del Mercado. Por lo tanto las organizaciones necesitan herramientas que les ayuden en su evolución para garantizar la satisfacción del cliente y ser más competitivas; incluido en estas herramientas está el ciclo PHVA, que permite mejorar continuamente los procesos de una organización y contribuye de manera beneficiosa a una organización, por esta razón este estudió apunta a un enfoque basado en la identificación de CTS y la implementación de un ciclo PHVA que es una herramienta de gestión en la cual esta metodología permitirá resolver problemas recurrentes crónicos determinando las causas de la calidad más importante. Problemas en el proceso de llenado, de la llenadora PACKER LLPAC-02, en el área de producción para resolver estos problemas que tiene un impacto en la empresa; primero, se lleva a cabo la identificación de los criterios de satisfacción de CTS en el proceso de llenado y luego se aplica la metodología del ciclo PHVA para determinar los problemas crónicos que afectan dicho proceso.
\end{abstract}


Este artículo tiene la intención de llevar a cabo un estudio de caso de una empresa del sector agroquímico para contribuir a su desarrollo y proporcionar beneficios con su implementación.

Palabras claves: proceso de llenado; criterios de satisfacción; reprocesamiento; ciclo de PHVA; relleno.

\section{Abstract}

Today organizations have the challenge of adapting to an environment that can be changing and unpredictable, with a high level of competence and demand to improve, grow and develop according to market needs.

Therefore, organizations need tools that help them in their evolution to ensure customer satisfaction and be more competitive; Included in these tools is the PHVA cycle, which allows to continuously improve the processes of an organization and contributes beneficially to an organization. For this reason, this study aims at an approach based on the identification of CTS and the implementation of a PHVA cycle that is a management tool in which this methodology will allow to solve recurrent and chronic problems by determining the root causes for the most important quality problems in the filling process of the PACKER LLPAC-02 filler, in the production area to solve these problems that have an impact on the company; First, the identification of CTS satisfaction critics in the filling process is carried out and then the PHVA cycle methodology is applied to determine the chronic problems that affect said process.

This article intends to carry out a case study of a company in the agrochemical sector to contribute to its development and provide benefits with its implementation.

Keywords: filling process; Critics of satisfaction; reprocessing; PHVA cycle; filler.

\section{INTRODUCTION}

The identification of the CTS in the industry is one of the most important items at present, which refers to the satisfaction critics where they are important for the client, because it shows the needs to the clients and they have great relevance at the time of having a product or a service, so it is necessary for organizations to meet and have standards which comply with these CTS for a satisfaction of which are essential for a company, in the same way the use of the PHVA cycle in industries generate an essential impact due to their effectiveness and effectiveness, being a dynamic and flexible model, which can be applied in different services or products that the organization has, as well as in the management system processes. Its great importance lies in helping to reduce costs, to the improvement of productivity, in the survival of the organization in an increasingly changing market.

The company will have a continuous improvement in its processes, generating great results and benefits. The application of the CTS identification and the use of the PHVA cycle will be carried out in the filling process of the PACKER filler. This study will contribute significantly to the main filling problems that are presented today, as well as in the claims that the clients show as they are badly labeled, bad capacity of the products, bad sealing of the containers, badly covered, among others. All these problems have generated negative impacts on the filling process, such as delays and reprocessing in production, thus generating low productivity, becoming the epicenter of various claims of non-compliant customers from different countries in which the products They are exported.

The impacts of improvement through the identification of the CTS and the PHVA cycle of this whole process will have a positive impact on the filling process, which will contribute to the improvement of the quality of the products in which it would solve The main problems that are presented in the filling and therefore would improve the quality of the products and reprocessing will contribute to the company in a significant way to the cost and time savings that are so important in the world of industry.

This article is organized and developed as follows: first, a literary review of the topic developed in the study is presented. Subsequently, we will present a methodology for the identification of CTS and through historical 
data provided by the company, and with the use of a Pareto chart we will identify the biggest problems that affect filling, and then we will apply the PHVA cycle in this process. Third, the real case study is carried out in an agrochemical company to demonstrate the feasibility of the proposed methodology, and finally have the improvements and impacts where the conclusions of this study are exposed.

\section{LITERATURE REVIEW}

Based on the need to address aspects relevant to the identification of CTS and the implementation of PHVA cycles in the control line, some experts propose some models and implementations that serve as a guide in organizations in order to improve their development processes for better results and increased productivity. This project is based on the substantial improvement of the efficiency of the beer packaging line, in a short period of time without increasing the cost. For this, a specific TPM team of operator training is used; the appropriate people are selected to constitute this team, from each department involved. This equipment was called "CGR AJUSTE DE CABEZAL DE ROSCADO B1200". A study and analysis of the fault data was carried out through the use of TPM tools (such as Cause - Effect Diagrams, 5 Why Analysis, Pareto Diagrams, etc.) and the team designed some steps to carry out the process: Detailed analysis of learning / development needs, appropriate to each type of job, Design of the learning situation and development of materials, Execution of the learning program and Evaluation of the results [1]. The project consists of intelligent product design through the implementation of a fuzzy and Kno-AHP-DEMATEL-QFD approach. This paper proposed a novel integration of fuzzy Kano, Analytic Hierarchy Process (AHP), Decision Making Trial and Evaluation Laboratory (DEMATEL), and Quality Function Deployment (QFD) to translate customer needs into product characteristics and prioritize design alternatives considering interdependence and vagueness. First, the customer requirements were established. Second, the fuzzy KANO was applied to calculate the impact of each requirement, often vague, on customer satisfaction. Third, design alternatives were defined, while the requirements 'weights were calculated using AHP. DEMATEL was later implemented for evaluating the interdependence among alternatives. Finally, QFD was employed to select the best design. A hip replacement surgery aid device for elderly [2].

The project is based on the packaging process that requires several operators who are responsible for dosing the product, adjusting the size of the product and covering the container. They determined tale stages as; when dosed, the second stage consists of a scale that is used to adjust the weight and size of the container and the third one where the lids are placed in the container containing the product. The main drawback in this process is the time it takes to finalize a container with the correct measure and covered. Production studies were carried out for the implementation of the project, control design through a machine that works autonomously and determining the possible reduction of laboratory production costs, It is feasible to automate the packaging process [3]. The main objective of this project was to conduct a feasibility study for the implementation of a new fully automated machinery, in the packaging, sealing and coding processes of the company ESKO LTDA, thus identifying current shortcomings within the production processes and offering possible solutions, in order to optimize time, raw materials and human resource expenses, thus generating greater competitiveness against the market in the cosmetic ind [4].

The purpose of the project is the implementation of the TPM methodology for the improvement of the operational efficiency of a packaging machine. Specifically, the machine to study object of this project, is in line 1300 of the packaging plant, critical according to factory objectives for Heineken España S.A. For the implementation of the methodology, work teams formed by people from different packaging departments were formed. After a loss analysis focused on the filling line, said analysis was performed through the study of a series of production indicators and the type of breakdowns that make the filling line critical, thus determining that most of the problems on the line they are resolved by improving the operational efficiency of the Riverwood packing machine. Already defined the most relevant concepts on operational efficiency and having assimilated the importance of the TPM methodology for the improvement of this, the steps to be followed in an improvement team to carry out its implantation in the factory were defined and developed [5]. 
The purpose of this project was to build on a study that would result in the feasibility of acquiring an adhesive filling machine for the repacking area of the Preflex S.A. production plant. They conducted a study using costbenefit and sensitivity analysis. This was based on the identification of quantitative and qualitative variables characteristic of the packaging system that the company is using, where aspects such as the quality of the final product marketed by the company, the filling times used for filling the units were identified finished, the percentage of waste during the current packaging process, the safety during packaging and product packaging, as well as the costs related to the production process of the product being marketed [6].

(Paloma \& Moreu, 2011).The objective of this project is based on improving the efficiency of a beer packaging line, without entailing an added cost and in a reduced time. For this, a study was conducted that allowed reducing the number of micro stops in a can grouping equipment, which has been detected as the most critical for the line in question, it should be noted that in addition to the reduction of the cans, also the staff Production of the line is usually an important element for the improvement of the process and that with the support of the PM pillar and the necessary training, learn to identify and classify them properly, so that you can stop them using simple instruments when this is possible and capable of restoring basic machine conditions in an increasingly autonomous way [7].

\section{THE PROPOSED METHODOLOGY}

The methodology was designed to improve the filling line of a company in the agrochemical sector through the application of CTS criteria and the PHVA cycle, which consists mainly of 2 phases: process analysis and identification of CTS and construction of the PHVA cycle.

The proposed objectives are listed in each phase, making a brief description of the activities that must be carried out and defining the results that must be achieved at the end of their application.

Phase 1 - process analysis and CTS identification [8]-[11]

Description of activities: the filling process of the PACKER LLPAC-02 filler is recognized, in which it is proposed to carry out a process diagram that allows to know in detail the stages of the process. After performing the process analysis, the identification of the CTS (Customer Satisfaction Criticism) is classified into CTD (Delivery Critic), CTQ (Quality Critic) and CTC (Cost Critic) according to their nature

Results: recognition of the filling process, process flowchart, customer satisfaction critics

Phase 2 - A Pareto chart is prepared and the PHVA cycle is developed.

Description of activities: a Pareto diagram is prepared in order to identify the potential causes of the noncompliant product in the filling process, then the application of the PHVA cycle in its planning stages, do, verify, and act. Where we seek to investigate the most important cause will be carried out through reviews that contemplate findings depending on them, a plan of measures to remedy the most important causes is focused on its execution and subsequently verification of the data obtained by comparing the different scenarios. Before the implementation and with the implementation of the cycle, in which recommendations and conclusions of the implementation carried out result.

Results: Pareto diagram and application of the PHVA cycle, conclusions and comparative evaluations of the implementation 


\section{CASE STUDY}

The agrochemical company in this case study is responsible for the production of insecticides, herbicides, which are intended for crop spraying, which

products are mostly exported to different parts of the world and a small amount are destined for national sale In this case study, the identification of CTS and application of a PHVA cycle in a PACKER LLPAC-02 filler that packages a herbicidal product (EC) (which is the only exclusive product that is filled in this filling line) is proposed. a company in the agrochemicals sector, since due to its high quality standards and maintaining a high productivity index and satisfied customers, the identification and implementation of mechanisms that reduce the current cost overrun and claims index derived from the problems of filling of the products, in such a way that the amount of reprocessing of the products and the delays in the production decrease, and little productivity and efficiency of the fillers that can generate all this type of inconvenience.

First phase: Analysis of the process and the identification of CTS.

In this first phase the different operations of the filling process were identified from the moment the container is entered until the moment it is in its stowage as a packed product, here it is identified the different quality controls which are in different stages of the filling process, which are highlighted in image 1, the processes and controls.

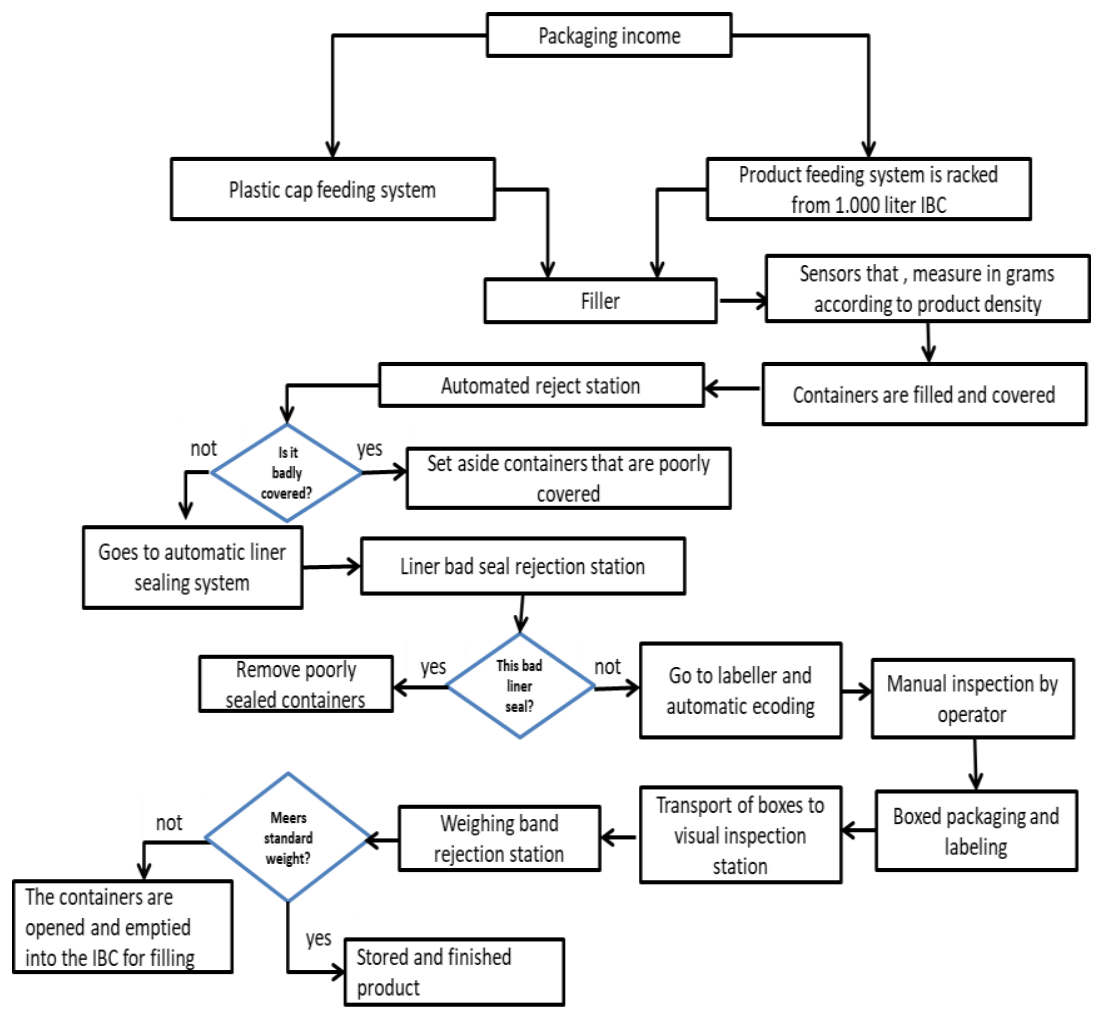

Fig 1. Flow chart of the filling process. Source: Authors 
In summary, the PACKER LLPAC-02 filler is packaged with an EC herbicide agrochemical product (CONCENTRATED EMULSION) and is made exclusively in this filling line, due to the color and demand characteristics of this product.

\begin{tabular}{|c|c|c|c|}
\hline \multicolumn{4}{|c|}{ CUSTOMER SATISFACTION CRITICISMS - PAKER PACKING FILLING PROCESS } \\
\hline CUSTOMER & \multirow{2}{*}{\multicolumn{2}{|c|}{$\begin{array}{l}\text { CTS (What contributes to customer satisfaction } \\
\text { (Interest Groups)? } \\
\text { What are the client's vital needs (Stakeholders)? }\end{array}$}} & CAUSAL PROCESSES \\
\hline & & & \\
\hline \multirow{8}{*}{$\begin{array}{l}\text { External } \\
\text { customer }\end{array}$} & \multirow[t]{5}{*}{ CTD } & Container labeling. & Filling-capping-sealing-labeling. \\
\hline & & $\begin{array}{l}\text { Good coding of the labels of the packages (date } \\
\text { of manufacture - expiration and lot number). }\end{array}$ & Filling-capping-sealing-labeling-coding. \\
\hline & & Packaging well packed in its box. & $\begin{array}{l}\text { Filling-capping-sealing-labeling-coding- } \\
\text { packaging. }\end{array}$ \\
\hline & & Well labeled box. & $\begin{array}{l}\text { Filling-capping-sealing-labeling-coding- } \\
\text { packing-labeling of house-coded box. }\end{array}$ \\
\hline & & $\begin{array}{l}\text { Well-coded box label (manufacturing-expiration } \\
\text { date and lot number). }\end{array}$ & $\begin{array}{l}\text { Filling-capping-sealing-labeling-coding- } \\
\text { packing-labeling of the house-coded etq.de } \\
\text { the box. }\end{array}$ \\
\hline & \multirow[t]{3}{*}{ CTQ } & Good sealing of the lainer. & Filling-capping-.sealing. \\
\hline & & Product well covered. & Filling-capping. \\
\hline & & Well-priced product. & Fill. \\
\hline
\end{tabular}

Table 1. Customer satisfaction criteria. Source: Authors.

The filling process is pneumatically by a compressed air system and the containers are transported throughout the filling process by conveyor belts and rollers. The filler has a system of feeding plastic caps $(25 \mathrm{~mm}$ with metal liner) and plastic containers (coex x 1 liter) and a product feeding system in which the product is transferred from IBC of 1000 liters to the filler, then It goes to the filler which has 7 filling guns with its respective platform where the sensor cells are located, the sensors are programmed in grams with respect to the density of the product and the volume to which the product has to be adjusted in this case $1000 \mathrm{cc}$, the containers are filled and capped on each platform and subsequently goes through an automated rejection station that separates the containers that are poorly capped, then goes to the liner sealing system by means of an induction sealer and then goes to the rejection station of poorly sealed by liner, which separates the containers that are poorly sealed with their liner automatically, then passes the containers to the labeller which They are automatically set by the the box, enters the containers are put in a cardboard box of 12 units of 1 liter content, which feed the machine, then they are labeled, with lot number, date of manufacture and expiration, then the boxes are transported by the same machine to the visual inspection station which an operator checks how the labeling and coding condition of the machine box comes out, then the box with the 12 containers inside it passes to the weighing band rejection station, where the box is passed by a band that in turn performs the weight of the box and if it does not meet the product, by policies the containers are ab open and emptied at the IBC for filling. The same procedure was followed with the identification of the CTS (Customer Satisfaction Criticism). 
The judgments issued by customers and production quality control and involved in the company's filling area were used thinking about the need for customer satisfaction.

Second phase: The Pareto diagram is prepared and the PHVA cycle is developed.

For this second phase, an information format is carried out where it was possible to collect data from the production reports of the last 4 months in a structured way, where the quantity of non-compliant product is quantified in general, as a result of the controls and inspections of the different stages of filling (see the cause of the non-compliant product packer)

\begin{tabular}{|l|l|l|l|l|l|l|}
\hline \multicolumn{7}{|c|}{ Causes non-conforming product in packer LLPAC -02 filler } \\
\hline Causes & June & July & $\begin{array}{l}\text { Augu } \\
\text { st }\end{array}$ & $\begin{array}{l}\text { Septem } \\
\text { ber }\end{array}$ & $\begin{array}{l}\text { October } \\
\text { (days 01 } \\
\text { to 15 })\end{array}$ & $\begin{array}{l}\text { Tota } \\
\text { 1 }\end{array}$ \\
\hline Bad storage of products & 1536 & $\begin{array}{l}184 \\
8\end{array}$ & 972 & 996 & 432 & 5784 \\
\hline Poor sealing of liners & 123 & 234 & 189 & 134 & 188 & 868 \\
\hline Poor labeling of containers & 103 & 288 & 122 & 203 & 75 & 791 \\
\hline $\begin{array}{l}\text { Poor covering of the sealing } \\
\text { machine }\end{array}$ & 100 & 279 & 149 & 50 & 43 & 621 \\
\hline $\begin{array}{l}\text { Miscoding of the packaging } \\
\text { label }\end{array}$ & 101 & 99 & 110 & 104 & 67 & 481 \\
\hline Poor labeling of the boxes & 54 & 86 & 76 & 77 & 110 & 403 \\
\hline Poor coding of boxes & 23 & 55 & 54 & 23 & 12 & 167 \\
\hline Poor packaging of boxes & 10 & 27 & 15 & 22 & 24 & 98 \\
\hline
\end{tabular}

Table 2. Causes of nonconforming product packer. Source: Authors.

Then with the collection of the information a Pareto diagram is made to prioritize the highest cause that results in non-compliant product in the filler. In which the highest cause of non-conforming product is generated by poor capacity of the products which represents $(62.78 \%)$ of non-conforming product presented by the filler.

In which the characterization of the problem for the application of the PHVA cycle is performed. Then, with the collection of the information, a Pareto diagram is made to prioritize the highest cause that results in noncompliant product in the filler.

\begin{tabular}{|c|c|c|c|c|}
\hline \multicolumn{5}{|c|}{ Pareto chart } \\
\hline & $\begin{array}{l}\text { Cause of } \\
\text { nonconforming } \\
\text { product }\end{array}$ & $\begin{array}{l}\text { Inventory } \\
\text { value }\end{array}$ & $\begin{array}{l}\text { Percentag } \\
\text { e share } \\
(\%)\end{array}$ & $\begin{array}{l}\text { Accumulated } \\
\text { percentage }(\%)\end{array}$ \\
\hline 1 & Poor product capacity & 5.784 & 62,78 & 62,78 \\
\hline 2 & Bad sealing of the sealer & 868 & 9,42 & 72,2 \\
\hline 3 & Poorly sealed liner & 791 & 8,59 & 80,79 \\
\hline 4 & $\begin{array}{ll}\text { Bad labeling of } \\
\text { packaging }\end{array}$ & 621 & 6,74 & 87,53 \\
\hline 5 & $\begin{array}{l}\text { Badly coded packaging } \\
\text { label }\end{array}$ & 481 & 5,22 & 92,75 \\
\hline 6 & Bad labeling of the box & 403 & 4,37 & 97,12 \\
\hline 7 & Badly coded box & 167 & 1,81 & 98,94 \\
\hline 8 & $\begin{array}{l}\text { Poorly packaged from } \\
\text { the box }\end{array}$ & 98 & 1,06 & 100 \\
\hline & Total & 9.213 & 100 & \\
\hline
\end{tabular}


Table 3. Causes of non-conforming products for Pareto chart. Source: Authors.

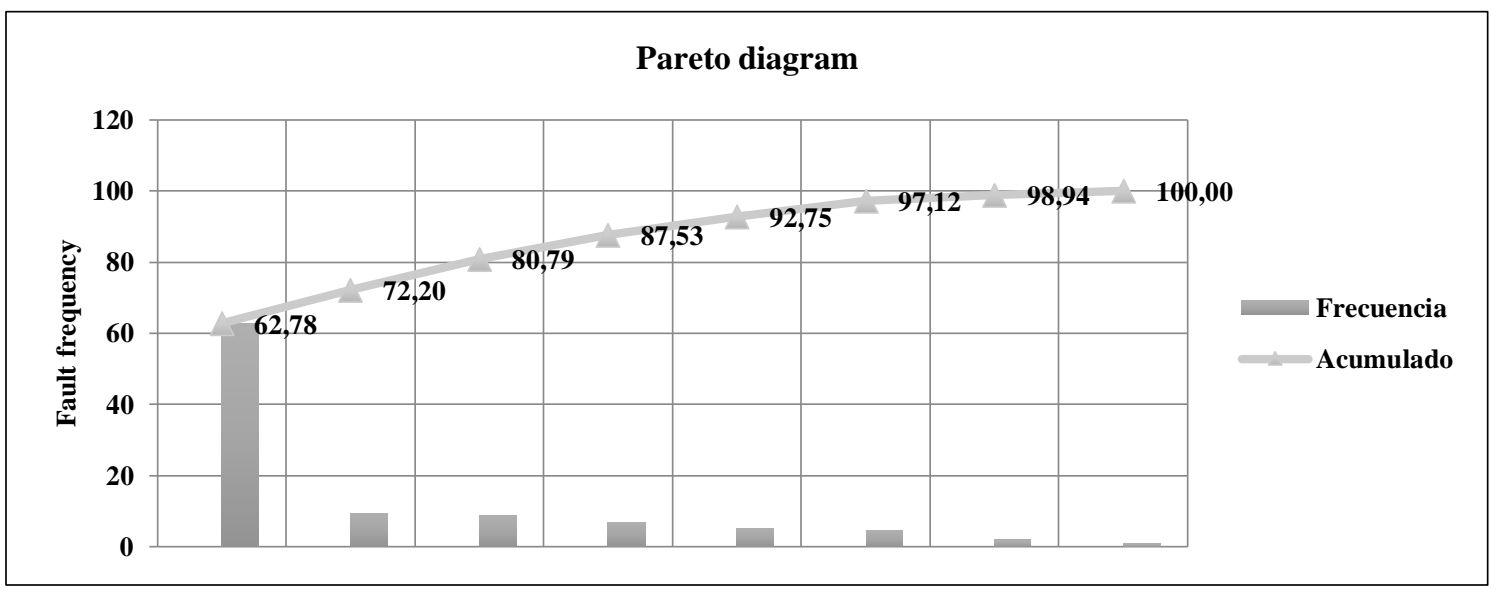

Fig 2. Pareto diagram. Source: Authors

The highest cause of non-compliant product is generated by poor capacity of the products which represents $(62.78 \%)$ of non-conforming product presented by the filler. In which the characterization of the problem for the application of the PHVA cycle is performed.

\begin{tabular}{|l|}
\hline Feature of the problema \\
\hline There is a growing trend and it is detected that the capacity of the presentation products of one liter of EC herbicide \\
product is outside the tolerance limit in which it presents problems in different periods of non-constant filling in a \\
variable way, where the filler gives 50 gram less weights than programmed, therefore it produces a poor capacity \\
of the stipulated volume when these problems occur, where the permissible tolerance is stipulated is \pm 5 grams.
\end{tabular}

\section{Table 4. Characteristics of the problem. Source: Authors.}

The root of this characteristic of the problem is the implementation of the PHVA cycle in which we initially enter and the scheme is performed through the Ishikawa diagram. For the search of all possible causes that generate this nonconformity then the investigation begins in which we identify the possible causes that generate the nonconformity in which the different findings are found, in which the department of maintenance, quality, and production participated by conducting relevant investigations corresponding to each cause identified. 


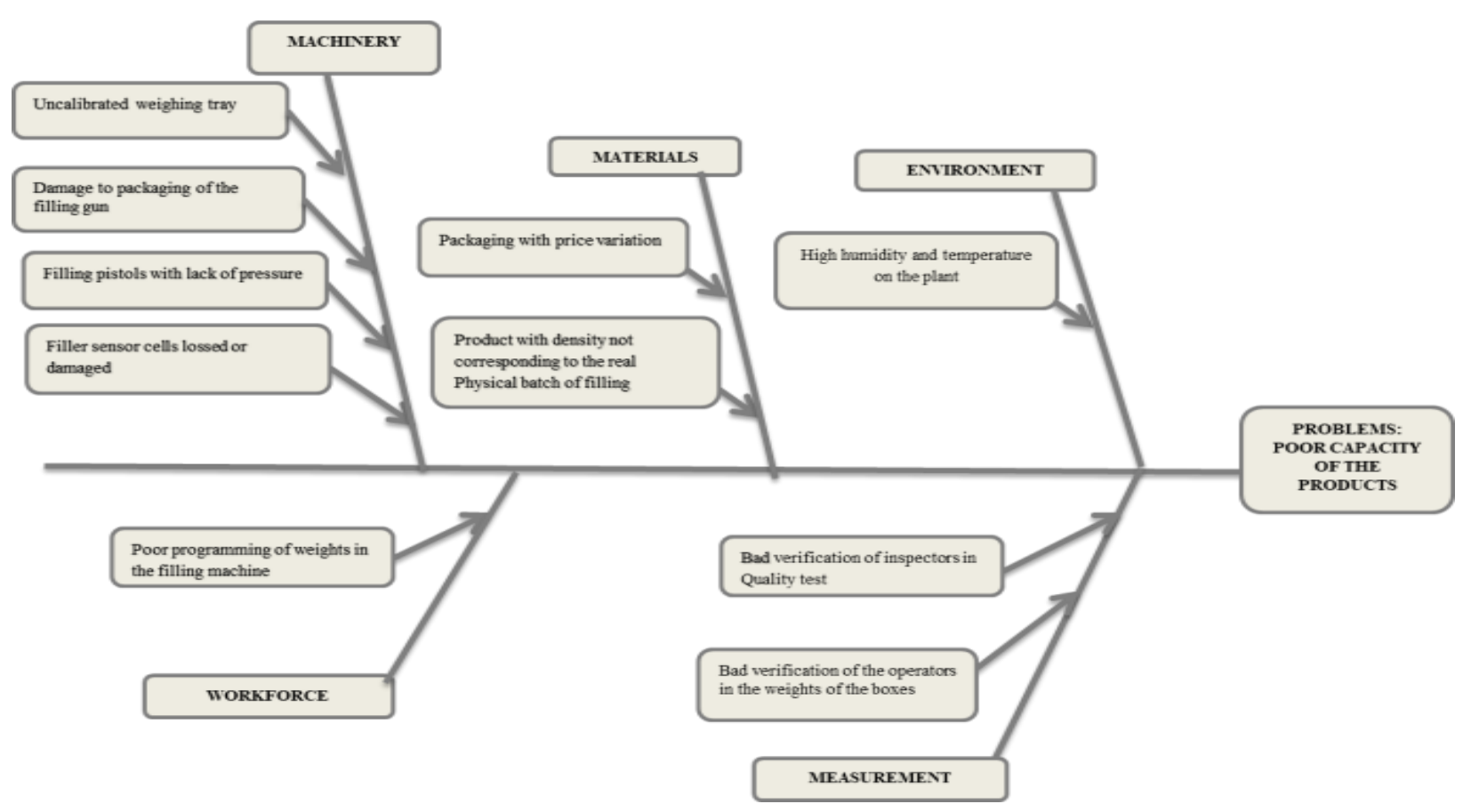

Fig 3. Ishikawa's diagram. Source: Authors

Investigation of the most important causes:

\begin{tabular}{|l|l|}
\hline Identified causes & Findings \\
\hline Filler sensor cells uncalibrated or damaged & $\begin{array}{l}\text { it was found that the } 7 \text { filling sensors are damaged reason why } \\
\text { they are uncalibrated }\end{array}$ \\
\hline filling guns with lack of pressure & $\begin{array}{l}\text { the psi that feed the filling guns were verified and complies with } \\
\text { the set pressure }(110 \mathrm{psi})\end{array}$ \\
\hline Damage to packing of the filling gun nozzles & $\begin{array}{l}\text { The nozzle packages were verified and found to be in good } \\
\text { condition. }\end{array}$ \\
\hline $\begin{array}{l}\text { bad programming of weights in the filling } \\
\text { machine }\end{array}$ & $\begin{array}{l}\text { supervision of the income of pesos in the filler was performed } \\
\text { and good programming was not found }\end{array}$ \\
\hline packaging with variation of weights & $\begin{array}{l}\text { Weighing of random batches of containers where they weighed } \\
105 \text { grams were performed and are within their allowable value } \\
\text { of the specification given by the supplier which is } \pm 2 \text { grams) }\end{array}$ \\
\hline $\begin{array}{l}\text { product with the density not corresponding to } \\
\text { the actual physical lot }\end{array}$ & $\begin{array}{l}\text { traceability of the lots was performed and all densities match the } \\
\text { physical lots }\end{array}$ \\
\hline high humidity in the plant & $\begin{array}{l}\text { temperature and humidity conditions were verified and it is } \\
\text { within parameters average temperature } 32^{\circ} \text { c humidity } 81 \%\end{array}$ \\
\hline $\begin{array}{l}\text { bad verification of the operators in the weight } \\
\text { of the boxes }\end{array}$ & $\begin{array}{l}\text { their activities and operators were checked if they verify the } \\
\text { weights of the containers well }\end{array}$ \\
\hline poor verification of inspectors in quality tests & $\begin{array}{l}\text { after analysis it was verified and the operators do not present } \\
\text { errors in the verifications }\end{array}$ \\
\hline Uncalibrated weighing band & I check the weighing band and it is calibrated \\
\hline
\end{tabular}

Table 5. Causes identified that will generate the problem. Source: Authors

The cause identified as "sensor cell of the filler uncalibrated or damaged ", was found as a finding that the 7 sensors which are damaged and uncalibrated, in which the maintenance department performed said review) and fault damage was found intermittent (given the end of life of the sensors) where from this we proceed to the elaboration of a plan of measures focused on remedying the most important cause of the filler problem. 
Measurement plan focused on remedying the most important causes:

\begin{tabular}{|l|l|}
\hline \multirow{4}{*}{$\begin{array}{l}\text { Uncalibrated } \\
\text { filler sensors }\end{array}$} & $\begin{array}{l}\text { MC: change and calibration of the } \\
\text { filler sensor cell }\end{array}$ \\
\cline { 2 - 2 } & $\begin{array}{l}\text { MP: make a mandatory daily } \\
\text { calibration plan for the sensor cells of } \\
\text { the filler }\end{array}$ \\
\cline { 2 - 2 } & $\begin{array}{l}\text { MP: carrying out a maintenance plan } \\
\text { and monthly verification of the sensor } \\
\text { cells }\end{array}$ \\
\hline $\begin{array}{l}\text { MP: implementation of a weighing } \\
\text { band with rejection system at the outlet } \\
\text { of the capper }\end{array}$ \\
\hline
\end{tabular}

Table 6. Plan of measures focused on remedying the most important cause. Source: Authors

We obtained $\mathrm{MC}=$ corrective measure and $\mathrm{MP}=$ preventive measures where the planned execution is carried out to remedy the most important causes and we have:

\begin{tabular}{|l|l|}
\hline Measurements & Implementation \\
\hline $\begin{array}{l}\text { MC: change and calibration of the filler sensor cell is } \\
\text { performed }\end{array}$ & $\begin{array}{l}\text { In a meeting with the maintenance team } \\
\text { and change and calibration of the sensor } \\
\text { cells was performed }\end{array}$ \\
\hline $\begin{array}{l}\text { MP: a mandatory daily calibration plan is made for } \\
\text { the sensor cells of the filler }\end{array}$ & $\begin{array}{l}\text { verification and calibration was } \\
\text { established starting workday in the } 6 \text { am } \\
\text { shift }\end{array}$ \\
\hline $\begin{array}{l}\text { MP: carrying out a monthly maintenance and } \\
\text { calibration plan for the sensor cells }\end{array}$ & $\begin{array}{l}\text { it was established that maintenance and } \\
\text { calibration of the sensor cells must be } \\
\text { carried out every first of each month }\end{array}$ \\
\hline $\begin{array}{l}\text { MP: implementation of a weighing band with } \\
\text { rejection system at the outlet of the capper }\end{array}$ & $\begin{array}{l}\text { will be established within the 2020 } \\
\text { budget }\end{array}$ \\
\hline
\end{tabular}

Table 7. Execution of remedial measures. Source: Authors

The implementation of the CM was carried out with the support of the maintenance group that worked hard in the shortest possible time for the change and calibration of the sensor cells of the filler and new ones that were stored in inventory were used. In which they obtained the following results:

\begin{tabular}{|c|c|}
\hline Before & After \\
\hline $\begin{array}{l}\text { There is a growing trend and the high index of non-compliant } \\
\text { product is detected due to the capacity problem in the filler which } \\
\text { does not meet the programmed weight for filling, but instead packs } \\
\text { less than the stipulated amount (50 grams less), which in the } \\
\text { inspection in the weighing band generates rejection which, it is } \\
\text { necessary to make the reprocessing of the product box of } 12 \text { units } x \\
1 \text { liters, which represents for the company } \$ 4,065 \text { pesos per } \\
\text { reprocessed container, and generation of delays in the process of } \\
\text { filling and fulfillment of order, where in the months of June-July- } \\
\text { August-September } 5352 \text { containers were reprocessed and in the } 15 \\
\text { days of October } 432 \text { of a total production of } 6336 \text { of packaged } \\
\text { product which this represents a } 6,8 \% \text { of non-compliant product due } \\
\text { to poorly priced product, representing } 1,756,080 \text { Colombian pesos in } \\
\text { money }\end{array}$ & $\begin{array}{l}\text { the quantity of non- } \\
\text { compliant product due to low } \\
\text { forum problems in which in } \\
\text { the first } 15 \text { days after the } \\
\text { corrective actions there was } \\
60 \text { non-compliant packages } \\
\text { from a packaging production } \\
\text { of } 6012 \text { packages which } \\
\text { represents } 0.99 \% \text { of non- } \\
\text { product compliant due to } \\
\text { poorly priced product, } \\
\text { representing } \$ 243,900 \\
\text { Colombian pesos in money }\end{array}$ \\
\hline
\end{tabular}

Table 8. Verification of the results obtained. Source: Authors. 
To prevent recurrence, the following was stipulated

\begin{tabular}{|l|l|}
\hline $\mathbf{a 1}$ & $\begin{array}{l}\text { change the procedure of calibration and preventive maintenance } \\
\text { of the sensor cells of the filler }\end{array}$ \\
\hline $\mathbf{a 2}$ & $\begin{array}{l}\text { socialize the new document to the operators and supervisors of } \\
\text { the process }\end{array}$ \\
\hline $\mathbf{a 3}$ & $\begin{array}{l}\text { fill out the list of assistance corresponding to the request for } \\
\text { changes }\end{array}$ \\
\hline $\mathbf{a 4}$ & $\begin{array}{l}\text { have a new procedure for consulting and inducing new staff and } \\
\text { progress }\end{array}$ \\
\hline
\end{tabular}

Table 9. Recurrence prevention. Source: Authors

In conclusion, a comparison is made of the above

\begin{tabular}{|c|c|}
\hline Before & After \\
\hline $\begin{array}{l}\text { There is a growing trend and the high index of non-compliant } \\
\text { product is detected due to the capacity problem in the filler which } \\
\text { does not comply with the established programmed filling weight } \\
\text { but rather weighs less than the stipulated amount ( } 50 \text { grams less) } \\
\text { when the tolerance is } \pm 5 \text { grams, which in the inspection in the } \\
\text { weighing band generates rejection which, it is necessary to make } \\
\text { the reprocessing of the product box of } 12 \text { units } 1 \text { liters, which } \\
\text { represents for the company } \$ 4,065 \text { pesos per reprocessed } \\
\text { container, and generation of delays in the process of filling and } \\
\text { order fulfillment, where } 5352 \text { were reprocessed in the months of } \\
\text { June-July-August-September }\end{array}$ & $\begin{array}{l}\text { There is a drop in the non-compliant } \\
\text { product, because the filler is filling } \\
\text { properly with the weight set for filling } \\
\text { within the tolerance of } \pm 5 \text { grams }\end{array}$ \\
\hline $\begin{array}{l}\text { In the first } 15 \text { days of the month of October, } 432 \text { containers left for } \\
\text { reprocessing a total production of } 6363 \text { of packaged product, } \\
\text { which represents } 6.81 \% \text { of non-compliant product due to poorly } \\
\text { adjusted product. }\end{array}$ & $\begin{array}{l}\text { The quantity of non-compliant product } \\
\text { due to low forum problems in which in } \\
\text { the first } 15 \text { days after of the corrective } \\
\text { actions there were a total of } 60 \text { non- } \\
\text { conforming containers that were } \\
\text { reprocessed from a } 6012 \text { packaging } \\
\text { production which represents } 0.99 \% \text { of } \\
\text { non-compliant product due to poorly } \\
\text { priced product }\end{array}$ \\
\hline $\begin{array}{l}\$ 1,756,080 \text { COP generated by non-compliant product due to } \\
\text { capacity problems taken from the last } 15 \text { days of October } \\
\text { production }\end{array}$ & $\begin{array}{l}\$ 243,900 \text { COP per non-compliant } \\
\text { product due to capacity problems taken } \\
\text { from the last } 15 \text { days of packaging after } \\
\text { implementation }\end{array}$ \\
\hline
\end{tabular}

Table 10. Conclusions and evaluation. Source: Authors

A comparison was made between 15 days before implementation and 15 days after the implementation of the PHVA cycle and reflects the following percentages and figures.

\begin{tabular}{|l|l|}
\hline $\begin{array}{l}\text { Packaged before implementation } \\
\text { month of October (15 days) }\end{array}$ & Units \\
\hline Non-conforming product & 432 \\
\hline Packaged product & 6336 \\
\hline
\end{tabular}

Table 11. Packaged before implementation (October first fortnight). Source: Authors 
Packaged before implementation month of october (15 days)

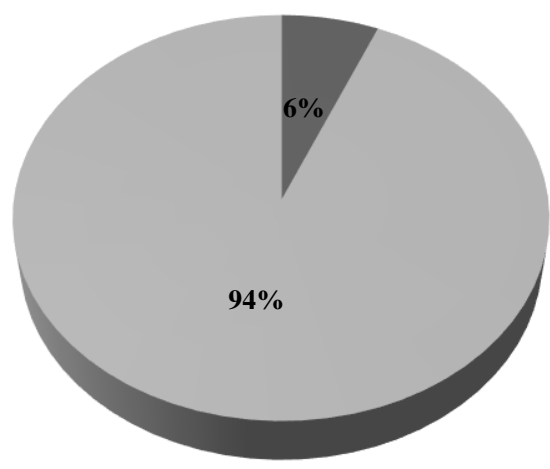

- Nonconforming

product

- packaged product

Fig 4. Non-compliant products by packaging before implementation. Source: Authors

\begin{tabular}{|l|l|}
\hline $\begin{array}{l}\text { Packaged before implementation month of } \\
\text { October (15 days) }\end{array}$ & $\begin{array}{l}\text { Quantity } \\
\text { units }\end{array}$ \\
\hline nonconforming product & 60 \\
\hline packaged product & 6012 \\
\hline
\end{tabular}

Table 12. Packaged before implementation (October second fortnight). Source: Authors.

Product does not conform after implementation

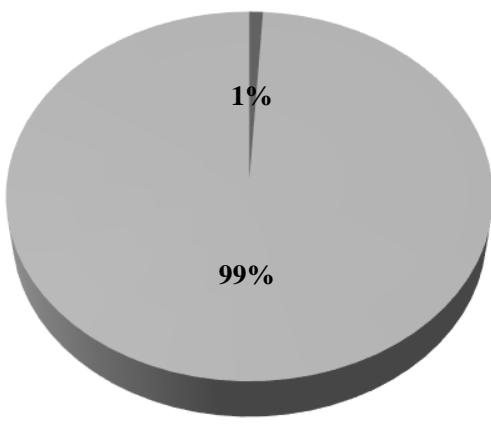

- Nonconforming product

packaged product

Fig 5. Non-conforming products by packaging after implementation. Source: Authors

A comparison was made and the value of the reprocessing of the non-compliant product is obtained from the months of June, July, August and September where we also have the average weekly value that the noncompliant product costs the company.

\begin{tabular}{|l|l|l|l|l|}
\hline Monthly reprocess cost of non-conforming product (product x 1 liter) \\
\hline Month & $\begin{array}{l}\text { Quantity of } \\
\text { product not } \\
\text { conforming } \\
\text { presentation } \\
\text { 1 liter }\end{array}$ & $\begin{array}{l}\text { Product } \\
\text { reprocess cost } \\
\mathbf{1} \text { liter }\end{array}$ & $\begin{array}{l}\text { Reprocess } \\
\text { cost per } \\
\text { product non- } \\
\text { monthly }\end{array}$ & $\begin{array}{l}\text { Average reprocess } \\
\text { cost per product non- } \\
\text { conforming weekly }\end{array}$ \\
\hline June & 1536 & $\$ 4.065$ & $\$ 6.243 .840$ & $\$ 1.441 .995$ \\
\hline July & 1.848 & $\$ 4.065$ & $\$ 7.512 .120$ & $\$ 1.734 .901$ \\
\hline August & 972 & $\$ 4.065$ & $\$ 3.951 .180$ & $\$ 912.513$ \\
\hline
\end{tabular}




\begin{tabular}{|l|l|l|l|l|}
\hline September & 996 & $\$ 4.065$ & $\$ 4.048 .740$ & $\$ 935.044$ \\
\hline Total & & & $\$ 21.755 .880$ & $\$ 5.024 .453$ \\
\hline
\end{tabular}

Table 13. Quantities of non-conforming products (June, July, August and September). Source: Authors

\section{Monthly reprocess cost of non-conforming product (product $\mathbf{x} 1$ liter)}

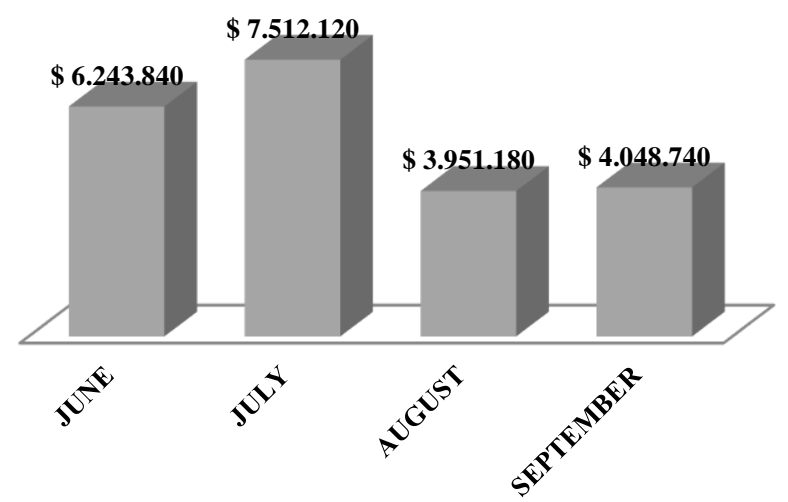

Fig 6. New process costs for non-conforming products. Source: Authors.

The graph shows the value that the agrochemical company costs said problem and the cost of reprocessing the non-compliant product every month where, in which averaging those months there is an estimated \$5.438.979 COP per month. The calculations of the first 15 days of the month of October (before the implementation of the PHVA cycle) are performed and the cost is calculated for the new non-conforming product process and the average calculation of the weekly non-conforming product cost and a weekly comparative with the 15 days following the implementation of the PHVA cycle.

\begin{tabular}{|c|c|c|c|c|}
\hline \multicolumn{5}{|c|}{$\begin{array}{l}\text { Product reprocess cost not conforming to the month of October before } \\
\text { implementation }\end{array}$} \\
\hline $\begin{array}{l}15 \text { Days of } \\
\text { production }\end{array}$ & $\begin{array}{l}\text { Quantity of } \\
\text { product not } \\
\text { conforming } \\
\text { presentation } \\
1 \text { liter }\end{array}$ & $\begin{array}{l}\text { Product } \\
\text { reprocess } \\
\text { cost } 1 \\
\text { liter }\end{array}$ & $\begin{array}{l}\text { Reprocess } \\
\text { cost per } \\
\text { non- } \\
\text { conforming } \\
\text { product (15 } \\
\text { days) }\end{array}$ & $\begin{array}{l}\text { Average } \\
\text { reprocess } \\
\text { cost per } \\
\text { product } \\
\text { non- } \\
\text { conforming } \\
\text { weekly }\end{array}$ \\
\hline October & 432 & $\$ 4.065$ & $\$ 1.756 .080$ & $\$ 813.000$ \\
\hline Total & & & $\$ 1.756 .080$ & $\$ 813.000$ \\
\hline
\end{tabular}

Table 14. Process costs for non-compliant products in October before implementation. Source: Authors 


\begin{tabular}{|c|c|c|c|c|}
\hline \multicolumn{5}{|c|}{$\begin{array}{l}\text { Product reprocess cost not conforming to the month of October after } \\
\text { implementation }\end{array}$} \\
\hline $\begin{array}{l}15 \text { Days of } \\
\text { production }\end{array}$ & $\begin{array}{l}\text { Quantity of } \\
\text { product not } \\
\text { conforming } \\
\text { presentation } \\
1 \text { liter }\end{array}$ & $\begin{array}{l}\text { Product } \\
\text { reprocess } \\
\text { cost } \quad 1 \\
\text { liter }\end{array}$ & $\begin{array}{l}\text { Reprocess } \\
\text { cost per } \\
\text { non- } \\
\text { conforming } \\
\text { product (15 } \\
\text { days) }\end{array}$ & $\begin{array}{l}\text { Average } \\
\text { reprocess } \\
\text { cost per } \\
\text { product } \\
\text { non- } \\
\text { conforming } \\
\text { weekly }\end{array}$ \\
\hline October & 60 & $\$ 4.065$ & $\$ 243.900$ & $\$ 112.917$ \\
\hline Total & & $\$ 243.900$ & $\$ 112.917$ & \\
\hline
\end{tabular}

Table 15. Process costs for non-compliant products in October after implementation. Source: Authors

It is taken as a reference 15 days before the implementation and 15 days after it where the values shown in the table are obtained and the great impact of the implementation of the PHVA cycle in the filling line can be observed, making a reduction of the It cost for new process.

\begin{tabular}{|l|l|l|}
\hline & $\begin{array}{l}\text { Comparison of weekly cost of product not } \\
\text { conforming before and after implementation } \\
\text { comparison of weekly cost of product not } \\
\text { conforming before and after implementation }\end{array}$ \\
\hline Before implementation & $\begin{array}{l}\text { After } \\
\text { implementation }\end{array}$ \\
\hline Costs & $\$ 813.000$ & $\$ 112.917$ \\
\hline
\end{tabular}

Table 16. Comparison of reprocessing costs before and after implementation. Source: Authors

A reduction of $86.11 \%$ like in (1) can be calculated with respect to costs due to the influence of the PHVA cycle implementation on the filling line

$$
\begin{gathered}
\text { \%improvement }=\frac{813.000-112.917}{813.000} * 100 \\
=86.11 \%
\end{gathered}
$$
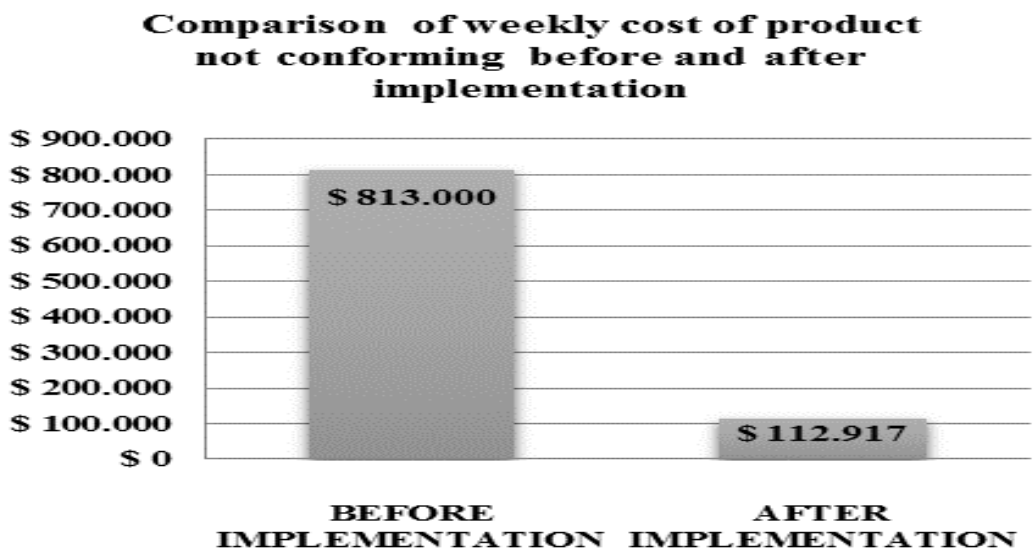

Fig 7. Comparison of reprocessing costs before and after implantation. Source: Authors 
A comparison is made of the units of the last 15 days before and 15 days after the implementation of the cycle where the following quantities data is abbreviated.

\begin{tabular}{|l|l|l|}
\hline \multirow{2}{*}{} & $\begin{array}{l}\text { Comparison of product amount not } \\
\text { conforming after } \\
\text { implementation }\end{array}$ \\
\cline { 2 - 3 } & $\begin{array}{l}\text { Before } \\
\text { implementation }\end{array}$ & $\begin{array}{l}\text { After } \\
\text { implementation }\end{array}$ \\
\hline Quantity & 432 & 60 \\
\hline
\end{tabular}

Table 17. Comparison of quantity of products before and after implementation. Source: Authors

A percentage improvement of 86.1 like in (2) can be calculated with respect to the quantities of non-compliant product before the implementation due to the influence of the PHVA cycle implementation on the filling line.

$$
\text { \%improvement }=\frac{432-60}{432} * 100=86.11 \%(2)
$$

\section{Comparison of product amount not conforming before and after implementation}

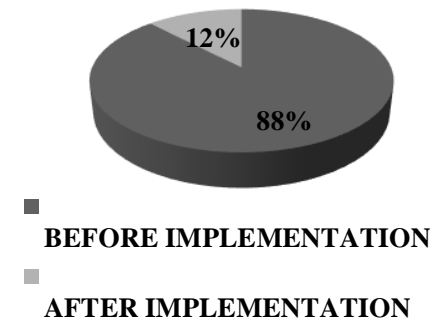

Fig 8. Comparison of quantity of nonconforming products, before and after implantation. Source: Authors

You can notice a decrease in the product units not in accordance with the implementation, generating an impact that benefits the company and is reflected in an improvement of its processes which have a great influence as previously observed in costs and in the same way there are more security in the processes that guarantee the compliance with the CTS and have satisfied customers for high quality products.

\section{CONCLUSIONS}

It is recommended the implementation of a PHVA cycle in the poorly sealed cause of the liner which is the second percentage of nonconforming product cause of the filling process in the packer llpac-02 filler in which the first was the gauging problems in which was carried out the implementation is worth highlighting that the preventive measure is taken into account (MP: implementation of a weighing band with rejection system at the exit of the capper) and it was reported that it will be established within the 2020 budget for its possible execution in the next year. For future work, it is recommended to focus on addressing the rest of non-conformity causes so that competitiveness of our products and services and quality can be improved while reducing the associated non-quality costs, improving the productivity and profitability of the company.

In the processes of the companies they must constantly look for different methods for the improvement of the quality and the efficiency of the processes, in which positive impact can be generated in the deficits that the companies have and it is indispensable that the companies take into account the critics customer satisfaction to provide good products that meet their expectations. With the application of the PHVA cycle in the right way, 
companies generate improvement in their part of quality, productivity and their financial part, these implementations strongly help to improve product quality, improve process efficiency and decrease rework and reprocessing.

The macro presented in this article allows us to observe the effectiveness of the identification of the CTS and the application of the PHVA cycle in filling line processes in which it significantly helps with quality improvement, reduces the costs caused by non-compliant products and optimizing the productivity of the processes, resulting in high quality products in which the process of filling a company in the agrochemical industry was taken as a case study, which shows its positive impact with the implementation of these methodology.

\section{FINANCING}

This project was fully supported by authors and Universidad de la Costa CUC.

\section{REFERENCES}

[1] Diego, G., Calder, M., \& Moreu, P. (2014). Improving the effectiveness of a beer bottling line by applying TPM. Universidad de Sevilla, Escuela Superior de Ingenieros. Departamento de Organización Industrial y Gestión de Empresas I, Ing. Quimica. Retrieved from http://bibing.us.es/proyectos/abreproy/20449/fichero/PFC_Diego_Moncayo.pdf

[2] Dionicio Neira,Miguel Ortiz, Sandra De la Hoz, Cristiano Paggetti,Laura Noffrini, N. F. (2020). applied sciences Smart Product Design Process through the Implementation of a Fuzzy. Universidad de La Costa, Barranquilla, Colombia.

[3] Juan José Contreras Hurtado. (2010). Design of Technical Systems, Industrial Maintenance, Project Management and Plastics of 2009 degree projects. Universidad EAFIT, Medellín, Colombia.

[4] Laura Ibarra. (2018). Feasibility study for the assembly of a packaging filling, sealing and coding machine that improves productivity in the cosmetics industry. Fundación Universidad de América, Facultad de Educación Permanente y Avanzada. Bogota. Retrieved from https://repository.uamerica.edu.co/bitstream/20.500.11839/7174/1/791344-2018-GE-II.pdf

[5] Manuel, P., \& Moreu, P. (2010). Improving the effectiveness of a beer bottling line by applying TPM. Universidad de Sevilla, Escuela Técnica Superior de Ingenieros de Sevilla. Departamento de Organización Industrial y Gestión de Empresas Ing. Industrial., (plan 98). Retrieved from http://bibing.us.es/proyectos/abreproy/4902/fichero/Proyecto.pdf

[6] Nelson, G., \& Gonzalez, C. (2017). Feasibility study for the acquisition of a filling machine in the company PREFLEX S.A. Universidad Distrital Francisco Jose de Caldas, Facultad Tecnológica. Bogota, 1-124. Retrieved from http://repository.udistrital.edu.co/bitstream/11349/6930/1/GonzalezDuarteCesarAugusto2017.pdf

[7] Paloma, B., \& Moreu, P. (2011). Study of a packaging line and application of the TPM Methodology to increase its efficiency, by reducing small stops in a grouping unit for cans packaging. Universidad de Sevilla, Escuela Superior de Ingenieros. Departamento de Organización Industrial y Gestión de Empresas, (Plan 98). Retrieved from http://bibing.us.es/proyectos/abreproy/4979/fichero/PFCPaloma+Barrera+Castellano.pdf

[8] Ortiz-Barrios, M. A., Herrera-Fontalvo, Z., Rúa-Muñoz, J., Ojeda-Gutiérrez, S., De Felice, F., \& Petrillo, A. (2018). An integrated approach to evaluate the risk of adverse events in hospital sector: From theory to practice. Management Decision, 56(10), 2187-2224. doi:10.1108/MD-09-2017-0917 
[9] Ortiz, M. A., \& López-Meza, P. (2016). Using computer simulation to improve patient flow at an outpatient internal medicine department doi:10.1007/978-3-319-48746-5_30

.[10] Ortiz-Barrios, M. A., Aleman-Romero, B. A., Rebolledo-Rudas, J., Maldonado-Mestre, H., Montes-Villa, L., De Felice, F., \& Petrillo, A. (2017). The analytic decision-making preference model to evaluate the disaster readiness in emergency departments: The A.D.T. model. Journal of Multi-Criteria Decision Analysis, 24(5-6), 204-226. doi:10.1002/mcda.1629

[11] Barrios, M. A. O., \& Jiménez, H. A. F. (2014). Metodología miceps para control estadístico de procesos: caso aplicado al proceso de producción de vidrio templado. Prospectiva, 12(2), 73-81. 